\title{
「高調波・無効電力」特集号の 編集に寄せて
}

\section{編集担当}

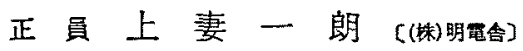

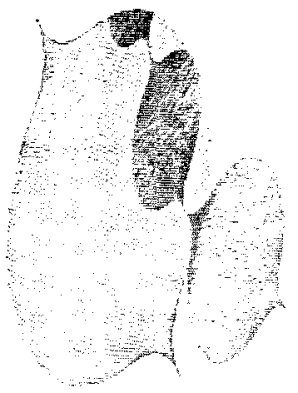

PWM 制御を初めとする最近の制湖技術の進歩で正 弦波入力形の制御が開発され，慗置自体であ加害者に ならないような工夫がされつつある。

尃用のフィルタ白従来の LC フィルタだりでなく， 能勤形の静止形高調波抑制装置(アクティフフィルタ) の研究開発が産学共同で進的られ，実用化の報告も次 々之されつつある。アクティブフィル夕は電力用半新 体のデバイスのスイッチング特性の改善に伴って, 速 応性が従来のICフィルタ上り飛躍的に改善され，単 に高調波の抑制だけでなく，落雷や電動機始動時に起 る瞬時電壬降下にも㤁動補正できるようになってきて いる。また遲れ，進みの電流制御が可能なため力率調 整の能力あある。そのほか, 従来のLCフィルタと組 合せてその特性を改善したり，反共振抑制る行える。 このようにアクティブフィルタは単なる高謂波揤制製 置でなく、多機能な電力系続改善装置としての発展を みせており，之の名称も変更しなければふさわしくな い技術の広がりをみせている。

とのように電力系統の質の改善力゙発展をみせている 時期汇「高調波・無効電力」という表題で特集解説を 企画したことは意羲のあるととと考える。解説は東京 工科大学の并上昌彦氏に「電力䒺統の高謂波之無効電 力対策」という表題で, 負荷と配電路線を含的た配電 系統の高調波，無勃電力の実態，それらの系統に与え

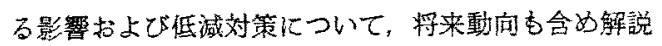
していただいた。日新電機の西台 惊氏には「高調波

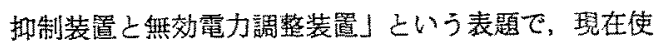

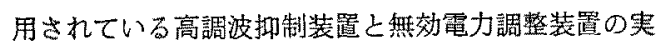
態, 能動形の高調波抑制装置, 筧効電力調整装置戈上 び最新の電力第半導体デバイス危用による将来勳向に ついて解説していただいた。

解説していただいたお二人は，表題に関し経䍄・学 識豊かなととは周知とおりであり、お杧しいなか執筆 隹頼を快く战引き受けいだだいたととを紙上をむって お礼由し上けます。

(昭和 63 年 10 月 31 日受付)

電源叟からみると整流器負荷となり高調波を流出する 加害者となる。しかし，これら加害者であった機器も 